\title{
Physiological profiles and sport specific fitness of Asian elite squash players
}

\author{
Ming-Kai Chin, ${ }^{1}$ Kurt Steininger, ${ }^{*}$ Raymond C H So, Christopher R Clarkt \\ and Alison S K Wong \\ Sports Science Department, Hong Kong Sports Institute, Hong Kong; *Department of Sports Medicine, \\ University of Ulm, Germany; and +Squash Department, Hong Kong Sports Institute, Hong Kong
}

\begin{abstract}
There is a scarcity of descriptive data on the physiological characteristics of elite Asian squash players. The purpose of this study was to evaluate the physiological profile and sports specific fitness of Hong Kong elite squash players. It was conducted before the selection of the Hong Kong national squash team for the 1992 Asian Squash Championship. Ten elite squash players were selected as subjects for the study. Maximum oxygen uptake was measured using a continuous treadmill running test. A sports specific field test was performed in a squash court. The following means(s.d.) were observed: height $172.6(4.3) \mathrm{cm}$; weight 67.7(6.9) $\mathrm{kg}$; body fat $7.4(3.4) \%$; forced vital capacity (FVC) 5.13(0.26) litres; maximum oxygen uptake $\left(\dot{V} \mathrm{O}_{\max }\right)$ $61.7(3.4) \mathrm{ml} \cdot \mathrm{kg}^{-1} \cdot \mathrm{min}^{-1}$; anaerobic threshold (AT) 80.2(3.3)\% of $\dot{\mathrm{V}} \mathrm{O}_{2 \max }$; alactic power index 15.5(1.8) $\mathrm{W} \cdot \mathrm{kg}^{-1}$; lactic work index $323.5(29.4) \mathrm{J} \cdot \mathrm{kg}^{-1}$, peak isokinetic dominant knee extensor and flexor strengths $3.11(0.29) \mathrm{Nm} \cdot \mathrm{kg}^{-1}$ and $1.87(0.18) \mathrm{Nm} \cdot \mathrm{kg}^{-1}$. The results show that the Hong Kong squash players have relatively high cardiorespiratory sports specific fitness and muscle strength which may be one of the key factors that contributed to the success of the Hong Kong team in the Asian Championship.
\end{abstract}

(Br J Sports Med 1995; 29 : 158-164)

Keywords: squash; elite athletes; oxygen uptake; isokinetic strength; anaerobic power; sports specific fitness

Squash at the elite level is primarily aerobic in nature, with intermittent bursts of activity being supplied from anaerobic energy sources. ${ }^{12}$ The champion needs both a wide range of skills and a high standard of fitness. Essentially squash fitness calls for stamina, strength, and physical agility besides the demand of high technical skill, good match temperament, and mental agility. ${ }^{3}$ Despite the growing popularity of squash, with increasing numbers of International Squash Racquets Federation (ISRF) members (from 67 to 100 in 1992) and a possible bid for participation in the Olympic Games for the year $2000,{ }^{4}$ studies of physiological characteristics of elite squash players are scarce. ${ }^{15-9}$ To the best of the authors' knowledge, there has only been one physiological study on Asian squash players which

Address for correspondence: Ming-Kai Chin PhD, Head, Sports Science, Sports Science Department, Hong Kong Sports Institute, Shatin, Hong Kong examined physiological alterations and leg strength following a three month training programme. ${ }^{10}$ The physiological data were for seven female and six male Malaysian players, who were not considered separately in the report.

In Hong Kong, the sport of squash is booming and is identified as the territory's fastest growing sport. Having witnessed an increase in participation of $150 \%$ over the past five years, the Hong Kong Squash Racquets Association (HKSRA) estimated there were no fewer than 60000 people playing the game on 700 courts around the Territory in 1990. ${ }^{11}$ Hong Kong has the largest league structure in Asia and the junior squash development programme is one of the healthiest in the world. ${ }^{12}$ At the sixth Asian Squash Championship, Hong Kong won the individual and team title, beating the favourite home team, Pakistan. Recently Hong Kong also captured the first ever individual title at the Asian Junior Championship held in Singapore in January 1993, breaking the five year winning streak of the Pakistanis. An examination of the physiological profiles and sports specific fitness of the Hong Kong elite squash players may provide some baseline data which can then be used by coaches, sports scientists, and future investigators to improve the performance of squash teams in international competition.

\section{Methods}

Ten top squash players served as subjects for this study before the selection of the Hong Kong national squash team for the Sixth Asian Squash Championship held at Peshawar, Pakistan, in January 1992. The four selected Hong Kong team members went on to win a gold medal in both the team and singles events at the championship. All subjects were either scholarship athletes of the Hong Kong Sports Institute (HKSI) or had represented Hong Kong in several international tournaments. As a group, they had accumulated a mean of nine years of playing experience. Athletes regularly underwent training, three hours per day, six days a week, for 11 months of the year. An average 70 matches was played by each player during the whole season. Informed consent was obtained from all subjects before the testing process. The test battery included measures of body com- 


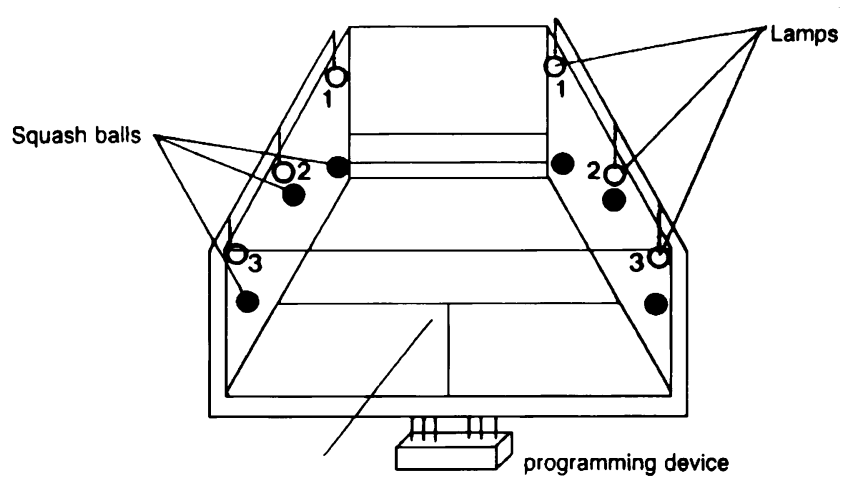

Figure 1. Squash field test

position, pulmonary function, maximum aerobic power, anaerobic threshold, anaerobic power, flexibility, and muscle strength. All tests with the exception of the sports-specific test took place at the human performance laboratory of the HKSI.

Percentage body fat was estimated from skinfold measurements using a Harpenden skinfold caliper (Quinton Instruments) at chest, abdomen, and thigh. ${ }^{13}$ Lean body weight (LBW) was calculated by the formula $(1-(\%$ fat $/ 100)) \times$ total body weight. A VitalographCOMPACT spirometer was used to evaluate pulmonary function by calculating the forced vital capacity (FVC), forced expired volume in $1 \mathrm{~s}\left(\mathrm{FEV}_{\mathrm{1} \cdot 0}\right)$, and maximum voluntary ventilation (MVV).

Sports specific fitness was measured according to a field test that has recently been developed to allow reliable estimates of the fitness of squash players. Its protocol has been described in detail elsewhere. ${ }^{14}$ Briefly, three lamps were positioned in a squash court on each of the side walls with a squash ball positioned under the lamps. The lamps were connected to a programming device located outside the court. Different fixed programmes (switch-in sequences of light flashes) were selected for each of the exercise intensities. The layout of the test is illustrated in Figure 1. The players were instructed to run from a central point towards each squash ball as soon as the corresponding bulb was lit and to strike the ball in a technically appropriate manner. The test consisted of successive 3 min periods of exercise. In the beginning 12 light pulses $\cdot \min ^{-1}$ were delivered, resulting in a total of 36 dashes at intensity level 1 . The intensity was then increased by six pulses (or dashes) per level until subjective exhaustion was reached, that is, until a lamp was lit before the preceding one was touched by the player. For determination of lactate concentration, blood was drawn from a hyperaemic ear lobe at rest during a $45 \mathrm{~s}$ rest interval interposed between each level of exercise period, and 1 and $3 \mathrm{~min}$ after cessation of activity. The value of $4 \mathrm{mmol} \cdot$ litre $^{-1}$ was taken as the anaerobic threshold. Heart rate readings were recorded with the Sport Tester $\mathrm{PE}_{4000}$ heart rate monitor (Polar Electro) throughout the whole testing period, and 1, 3, and $5 \mathrm{~min}$ after the termination of activity.

Maximum oxygen uptake, $\dot{\mathrm{V}} \mathrm{O}_{2 \max }$ was measured using a continuous running test performed on a Quinton 65 treadmill (Quinton Instruments). All subjects were familiarized with the testing procedures before data collection. Following a $10 \mathrm{~min}$ warm up at $8.05 \mathrm{~km} \cdot \mathrm{h}^{-1}$ ( $0 \%$ grade), the subject began running at a velocity of $12.1 \mathrm{~km} \cdot \mathrm{h}^{-1}$ ( $0 \%$ grade). Every $2 \mathrm{~min}$ thereafter, the grade was increased by $2.5 \%$ until volitional exhaustion, Metabolic and respiratory measurements were obtained using a Sensormedics 2900 Energy Expenditure Unit connected with a Sensormedics SP2401 ECG monitor (formerly Gould 2900; Sensormedics) and included heart rate, expiratory minute volume $\left(\dot{\mathrm{V}}_{\mathrm{E}}\right), \dot{\mathrm{V}} \mathrm{O}_{2}, \dot{\mathrm{V}} \mathrm{CO}_{2^{\prime}}$ respiratory quotient, $\mathrm{FECO}_{2}$, and $\mathrm{O}_{2}$ pulse which were computed and displayed every $20 \mathrm{~s}$. Anaerobic threshold measurements were determined by observing the onset of the non-linear relationship between $\mathrm{VO}_{2}$ and $\dot{\mathrm{V}}_{\mathrm{E}}-\dot{\mathrm{V}} \mathrm{CO}_{2}$; and were expressed relative to oxygen consumption (percentage $\dot{\mathrm{V}}_{2 \max }$ ) and heart rate percentage $\left(\mathrm{HR}_{\max }\right)$. At 1, 3, and $5 \mathrm{~min}$ of recovery, $25 \mu \mathrm{l}$ of blood were sampled from the earlobe. Blood lactate (LA) concentrations were determined using an Analox GM7 lactate analyser (Analox Instruments).

Anaerobic power was measured according to the procedure that has been developed to accompany the REPCO front access cycle ergometer in detail elsewhere. ${ }^{1617}$ Briefly, the subject was required to perform a maximum effort standing cycle test over $10 \mathrm{~s}$ to assess work capacity and peak power. After another 2 min rest, the squash player was required to perform $30 \mathrm{~s}$ of maximal standing cycle ergometry.

Maximum strength of extensor and flexor muscles of each knee was measured using an isokinetic dynamometer (Cybex II +, Lumex). After a warm up, five consecutive maximal contractions were performed at $60^{\circ} \cdot \mathrm{s}^{-1}$; peak torque was recorded as the highest value of the trials. The strength ratio between knee flexors and knee extensors of each leg (hamstring:quadriceps $(\mathrm{H}: \mathrm{Q})$ ratio) was also calculated. Grip strength of the preferred arm was measured using a grip dynamometer (Takei, No 1201, Japan). Each subject performed three trials and the best score was recorded.

Flexibility of the hip joint, trunk, and hamstring muscles was tested by the sit-and-reach test. ${ }^{18}$ After gentle stretching during two or three warm-up trials on the hamstring muscles three trials were carried out and the maximum value recorded.

All values in the text, figures, and tables are expressed as mean(s.d.).

\section{Results}

The physical characteristics of the subjects are displayed in Table 1. The selected pulmonary function measurements, aerobic capacity, and cardiorespiratory fitness

Table 1. Physical characteristics of Hong Kong elite squash players $(n=10)$

\begin{tabular}{lc}
\hline Variables & Mean(s.d.) (range) \\
\hline Age (years) & $20.7(2.5)(18-26)$ \\
Height $(\mathrm{cm})$ & $172.6(4.3)(166-180)$ \\
Weight $(\mathrm{kg})$ & $67.7(6.9)(60-83)$ \\
Lean body weight $(\mathrm{kg})$ & $63.2(5.0)(57-70)$ \\
Body fat $(\%)$ & $7.4(3.4)(4.7-16.0)$ \\
\hline
\end{tabular}


Table 2. Selected pulmonary function measurements, aerobic capacity and cardiorespiratory fitness of Hong Kong elite squash players in treadmill running $(n=10)$

\begin{tabular}{|c|c|}
\hline Variables & Mean(s.d.) (range) \\
\hline FVC (I) & $5.13(0.26)(4.70-5.60)$ \\
\hline $\mathrm{FEV}_{1.0}(\mathrm{I})$ & $4.33(0.23)(3.96-4.79)$ \\
\hline $\mathrm{FEV}_{1.0}^{1.0}(\%)$ & $84.4(4.4)(80.0-92.0)$ \\
\hline $\operatorname{MVV}\left(1 \cdot \min ^{-1}\right)$ & $176.3(18.6)(150.0-201.0)$ \\
\hline $\mathrm{VO}_{2 \max }\left(1 \cdot \min ^{-1}\right)$ & $4.21(0.42)(3.48-4.82)$ \\
\hline$\dot{V} \mathrm{O}_{2 \max }\left(\mathrm{ml} \cdot \mathrm{kg}^{-1} \cdot \mathrm{min}^{-1}\right)$ & $61.7(3.4)(56.3-67.4)$ \\
\hline$H R_{\max }\left(\right.$ beats $\left.\cdot \min ^{-1}\right)$ & $190.7(7.2)(181.0-201.0)$ \\
\hline$\dot{\mathrm{V}}_{\mathrm{Emax}}^{\max }\left(\mathrm{I} \cdot \min ^{-1}\right)$ & $130.8(20.4)(106.7-144.0)$ \\
\hline $\mathrm{O}_{2}$ pulse $\left(\mathrm{ml} \cdot\right.$ beat $\left.^{-1}\right)$ & $22.7(3.6)(17.4-27.1)$ \\
\hline $\begin{array}{l}\text { Respiratory exchange ratio } \\
\text { (RQ) }\end{array}$ & 1.15(0.08) (1.10-1.38) \\
\hline $\begin{array}{l}\dot{\mathrm{VO}} \text { at anaerobic threshold } \\
\left(\mathrm{ml} \cdot \mathrm{kg}^{-1} \cdot \mathrm{min}^{-1}\right)\end{array}$ & $49.5(3.3)(43.5-54.0)$ \\
\hline AT $\left(\% \dot{V}_{2 \max }\right)$ & $80.1(4.9)(70.3-87.1)$ \\
\hline $\begin{array}{l}\text { HR at anaerobic threshold } \\
\text { (beats } \cdot \min ^{-1} \text { ) }\end{array}$ & $168.3(9.1)(156.0-180.0)$ \\
\hline AT $\left(\% H R_{\max }\right)$ & $89.8(2.9)(84.5-94.0)$ \\
\hline $\mathrm{LA}_{\max }\left(\mathrm{mmol} \cdot \mathrm{I}^{-1}\right)$ & $11.0(1.3)(8.4-12.6)$ \\
\hline
\end{tabular}

FVC $=$ forced vital capacity; FEV $_{1 \cdot 0}=$ forced expiratory volume at $1.0 \mathrm{~s} ; \mathrm{MVV}=$ maximum voluntary ventilation; $\mathrm{LA}=$ blood lactate concentration; AT = anaerobic threshold

data in treadmill running are given in Table 2. Results of the field test for individual players are presented in Table 3 , and Figures 2 and 3. The anaerobic power data of the Hong Kong squash players and a comparison with other Hong Kong and Australian elite athletes are presented in Table 4. Peak torque outputs of dominant knee with comparative figures from Hong Kong and other national sportsmen (all measured in $\mathrm{Nm} \cdot \mathrm{kg}^{-1}$ at $60^{\circ} \cdot \mathrm{s}^{-1}$ ) are presented in Table 5.

\section{Discussion}

\section{Anthropometry}

Data on height (mean(s.d.) $172.6(4.3) \mathrm{cm}$ ) and weight (mean(s.d.) 67.7(6.9) kg) seem to support other findings that competitive players tend, on average, to be close to

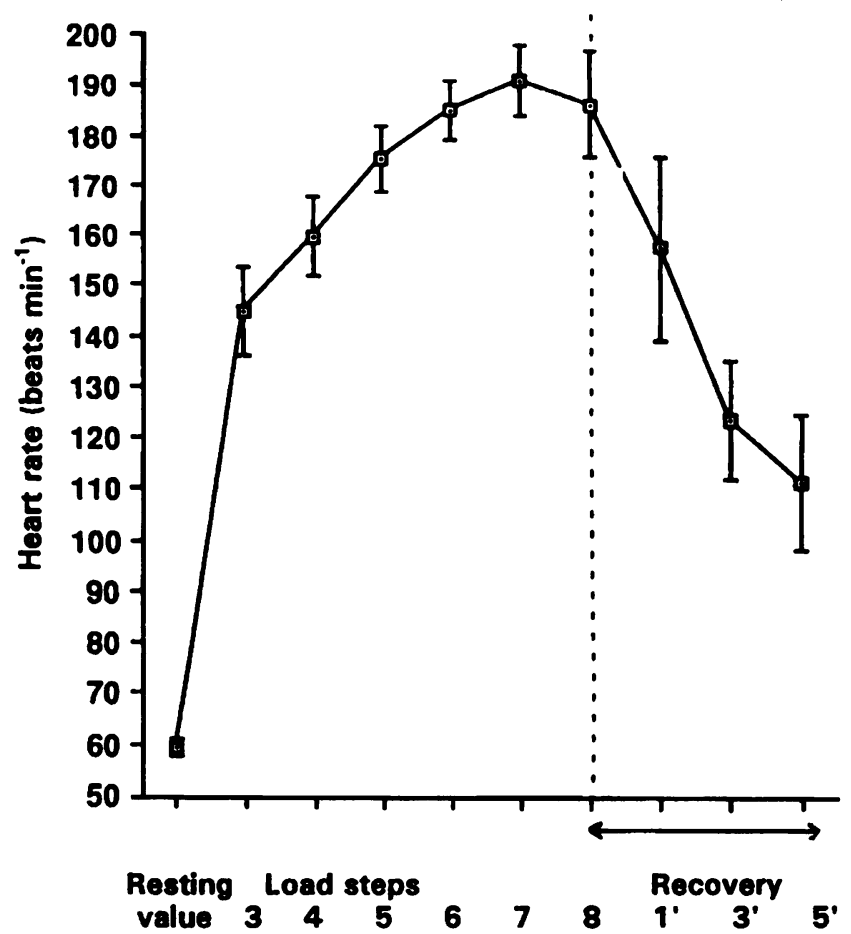

Figure 2. Heart rate responses in the field test $(n=10)$

population norms. ${ }^{19}$ Generally the body fat percentage of a man in his mid-twenties is about $15-16 \%$ of body weight and the figures for trained athletes are usually much less. ${ }^{20}$ For top competitive players, body fat composition tends to be low, as the negative impact of excess body fat would increase the energy expended in moving around the squash court. The subjects used in the study were lean, with a mean(s.d.) percentage body fat of 7.4(3.4)\% which appears to be lower than that of Western Australian players (12.0\%), ${ }^{21}$ and elite South African squash players $(10.1 \%){ }^{5}$ It is suggested that at a good international level $10 \%$ is the upper limit for elite squash players. ${ }^{22}$ However, the variability in body composition among athletes participating in the same sport could be due to the natural variation in body fat,

Table 3. Results of the field test for individual players

\begin{tabular}{|c|c|c|c|c|c|c|c|}
\hline \multirow[b]{2}{*}{ Subject } & \multirow[b]{2}{*}{$\begin{array}{c}H R_{\max } \\
\left(\text { beats } \cdot \min ^{-1}\right)\end{array}$} & \multirow[b]{2}{*}{$\begin{array}{l}\text { Heart rate } 5 \text { min } \\
\text { after load end }\end{array}$} & \multirow[b]{2}{*}{$\underset{\left(\left.m \operatorname{mol} \cdot\right|^{-1}\right)}{L A_{\max }}$} & \multicolumn{2}{|c|}{$\begin{array}{l}\text { Maximum } \\
\text { performance }\end{array}$} & \multirow{2}{*}{$\begin{array}{l}\text { Performance at } \\
\text { the anaerobic } \\
\text { threshold (light } \\
\text { pulses } \cdot \mathrm{min}^{-1} \text { ) }\end{array}$} & \multirow{2}{*}{$\begin{array}{c}H R \text { at the } \\
\text { anaerobic } \\
\text { threshold } \\
\left(\text { beats } \cdot \min ^{-1} \text { ) }\right.\end{array}$} \\
\hline & & & & load & $\begin{array}{l}\text { Time } \\
(\min )\end{array}$ & & \\
\hline 1 & 195 & 123 & 9.8 & 7 & 2.0 & 18.7 & 166 \\
\hline 2 & 190 & 104 & 7.3 & 7 & 1.3 & 20.6 & 175 \\
\hline 3 & 196 & 125 & 10.2 & 6 & 2.7 & 18.0 & 165 \\
\hline 4 & 200 & 118 & 9.1 & 7 & 2.7 & 20.7 & 175 \\
\hline 5 & 197 & 90 & 8.9 & 8 & 1.6 & 19.3 & 175 \\
\hline 6 & 176 & 96 & 12.3 & 7 & 1.3 & 18.7 & 160 \\
\hline 7 & 200 & 112 & 11.1 & 7 & 1.4 & 20.0 & 179 \\
\hline 8 & 188 & 129 & 15.9 & 6 & 1.5 & 17.3 & 165 \\
\hline 9 & 189 & 109 & 11.3 & 6 & 1.8 & 16.7 & 175 \\
\hline 10 & 196 & 127 & 12.1 & 7 & 2.0 & 19.3 & 175 \\
\hline Means(s.d.)* & $192.7(6.8)$ & $113.3(12.8)$ & $10.8(2.2)$ & 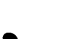 & & $19.0(1.4)$ & $171.0(6.0)$ \\
\hline
\end{tabular}

$\mathrm{LA}=$ blood lactate

${ }^{*} n=10$ 


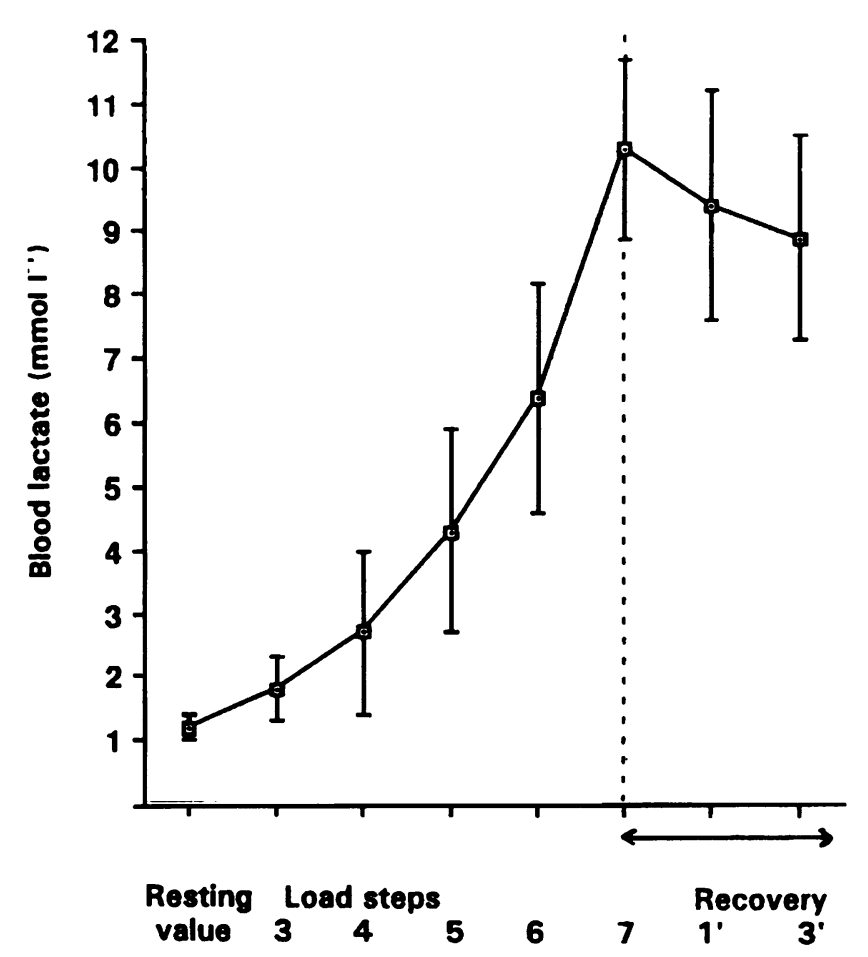

Figure 3. Blood lactate values in the field test $(n=10)$

eating, and exercise pattern. Instead of establishing a specific body fat value, a range of acceptable values could be proposed for monitoring the performance and health of the athlete. ${ }^{23}$

\section{Pulmonary function}

All pulmonary function variables measured in this study were above normal limits for the 19-24 year age group of Hong Kong Chinese. ${ }^{24}$ The FVC of 5.13(0.26) litres appears to be comparable to the Hong Kong national soccer team $(5.10)^{25}$ but lower than that of elite European road cyclists $(5.91)^{26}$ and top South African squash players $(6.32) .^{5}$ The mean(s.d.) FEV $_{10}(4.33(0.23)$, percentage FVC (84.4(4.4)), and MVV (176.3(18.6)) observed in this study showed a high efficiency of the respiratory muscles by which air can be breathed in and out to furnish the oxygen transport system. This is not
Table 5. Peak torque outputs of the knee-comparative figures from Hong Kong ${ }^{25}$ and other national sportsmen ${ }^{48-50}$ (all measured in $\mathrm{Nm} \cdot \mathrm{kg}^{-1}$ at $60^{\circ} \cdot \mathrm{s}^{-1}$ ). Data are presented for the dominant knee

\begin{tabular}{lcccc}
\hline & & & & $\begin{array}{c}\text { Flexion: } \\
\text { extension } \\
\text { ratio (\%) }\end{array}$ \\
Sports & $\mathrm{n}$ & Extension* & Flexion* & \\
\hline $\begin{array}{c}\text { Squash (HK team) } \\
\text { present study }\end{array}$ & 10 & $3.11(0.38)$ & $1.87(0.18)$ & 62.0 \\
$\begin{array}{c}\text { Squash (Singapore } \\
\text { team) }\end{array}$ & 15 & $2.74(0.39)$ & $1.63(0.24)$ & 59.4 \\
$\begin{array}{c}\text { Squash (Australian } \\
\text { junior U20 team) }\end{array}$ & 12 & $2.58($ n.a.) & $1.54($ n.a.) & 59.6 \\
$\begin{array}{c}\text { Tennis (Australian } \\
\text { team) }\end{array}$ & 9 & $2.74($ n.a.) & $1.91($ n.a.) & 69.7 \\
$\begin{array}{c}\text { Badminton (HK } \\
\text { team) }\end{array}$ & 11 & $3.42(0.43)$ & $1.89(0.28)$ & 55.5 \\
$\begin{array}{c}\text { Soccer (HK team) } \\
\text { Soccer (China } \\
\text { team) }\end{array}$ & 24 & $2.72(0.36)$ & $1.65(0.20)$ & 60.0 \\
$\begin{array}{c}\text { Soccer (Singapore } \\
\text { team) }\end{array}$ & 14 & $3.10(0.33)$ & $1.60(0.19)$ & 51.7 \\
$\begin{array}{c}\text { Cycling (HK team) } \\
\text { Cycling (China } \\
\text { team) }\end{array}$ & 10 & $2.66(0.57)$ & $1.60(0.41)$ & 60.2 \\
\hline
\end{tabular}

HK = Hong Kong

*Values are mean(s.d.); n.a. not available

surprising as training for competitive squash requires high intensity, very short interval action (10 to $20 \mathrm{~s}$ ) with a work to rest ratio of $1: 1 .^{6}$

\section{Cardiorespiratory fitness}

The maximum aerobic power of elite squash players appears to be around 56 to $64 \mathrm{ml} \cdot \mathrm{kg}^{-1} \cdot \mathrm{min}^{-1}, 15914$ which reflects the higher aerobic demand of this sport compared with tennis and badminton, ${ }^{19}$ with intermittent bursts of activity that involve very short work to rest intervals. Mean(s.d.) $\mathrm{VO}_{2 \max }$ values (61.7(3.4) $\mathrm{ml} \cdot \mathrm{kg}^{-1} \cdot \mathrm{min}^{-1}$ ) for the subjects in this study appeared to be higher than those values reported for the 'high level' Canadian players $\left(56.0 \mathrm{ml} \cdot \mathrm{kg}^{-1} \cdot \mathrm{min}^{-1}\right)^{9}$ and elite Australian players $\left(57.8 \mathrm{ml} \cdot \mathrm{kg}^{-1} \cdot \mathrm{min}^{-1}\right)^{1}$ but were comparable to that of the top South African players $\left(59.5 \mathrm{ml} \cdot \mathrm{kg}^{-1} \cdot \mathrm{min}^{-1}\right){ }^{5}$ However, $\mathrm{VO}_{2 \max }$ values are not expected to reach the same level as in endurance sports

Table 4. Anaerobic power tests - comparative figures from Hong Kong ${ }^{25}$ and Australian team athletes ${ }^{1517}$

\begin{tabular}{lrrrr}
\hline Sports & $\mathrm{n}$ & $\begin{array}{c}\text { Alactic power } \\
\text { index }\left(W \cdot \mathrm{kg}^{-1}\right)^{*}\end{array}$ & $\begin{array}{c}\text { Alactic work } \\
\text { index }\left(J \cdot \mathrm{kg}^{-1}\right)^{*}\end{array}$ & $\begin{array}{c}\text { Lactic work } \\
\text { index }\left(J \cdot \mathrm{kg}^{-1}\right)^{*}\end{array}$ \\
\hline Squash (HK team) present study & 10 & $15.5(1.8)$ & $127(17)$ & $324(29)$ \\
Soccer (HK team) & 24 & $13.5(2.4)$ & $103(20)$ & $298(27)$ \\
Cycling-road (HK team) & 6 & $17.0(2.0)$ & $131(17)$ & $315(23)$ \\
Badminton (HK team) & 8 & $17.1(2.0)$ & $138(13)$ & $332(22)$ \\
Squash (Australian State team) & 7 & $14.7(2.1)$ & $118(15)$ & $318(19)$ \\
Swimming (Australian National team) & 63 & $14.3(1.5)$ & $118(13)$ & $299(26)$ \\
Volleyball (Australian National team) & 16 & $16.3(1.6)$ & $131(14)$ & $291(32)$ \\
Rugby/Touch (Australian U20 National team) & 30 & $14.5(1.5)$ & $121(14)$ & $293(21)$ \\
Middle distance running (Australian State/National team) & 8 & $15.6(1.4)$ & $121(12)$ & $321(19)$ \\
Long distance running (Australian State/National team) & 9 & $11.9(1.7)$ & $93(15)$ & $275(42)$ \\
\hline
\end{tabular}

$\mathrm{HK}=$ Hong Kong

*Values are mean(s.d.) 
such as cycling, distance running, and rowing. The 1988 Hong Kong Olympic cyclists tested in our laboratory $(n=8)$ had a mean(s.d.) value of 72.1(3.0) $\mathrm{ml} \cdot \mathrm{kg}^{-1} \cdot \mathrm{min}^{-1}$ (range $\left.69-77 \mathrm{ml} \cdot \mathrm{kg}^{-1} \cdot \mathrm{min}^{-1}\right){ }^{27}$

The mean(s.d.) maximum heart rate (190.7(7.2) beats $\cdot \mathrm{min}^{-1}$ ) of the subjects tend to be lower than that of the German squash players $\left(195(6.0) \text { beats } \cdot \min ^{-1}\right)^{14}$ and similar to that of top South African squash players (184(9.0) beats $\left.\cdot \mathrm{min}^{-1}\right)^{5}$ and players of intermediate ability $\left(186(8.0)\right.$ beats $\left.\cdot \min ^{-1}\right) .^{28}$ The $\dot{V}_{\text {Emax }}$ values found in the current study $\left(130.8(20.4)\right.$ litre $\left.\cdot \mathrm{min}^{-1}\right)$ were comparable to those of the Hong Kong national soccer team (136.0(13.4) litres $\left.\cdot \mathrm{min}^{-1}\right)^{25}$ but tended to be lower than the Hong Kong national rowing team (178.9(16.0) litres $\left.\cdot \min ^{-1}\right) .9$ This is to be expected as exercise during squash and soccer are of an intermittent nature while rowing is a continuous activity. The oxygen pulse value of the subjects $\left(22.7(3.6) \mathrm{ml}^{\cdot}\right.$ beat $\left.^{-1}\right)$, an indirect measurement of stroke volume of the heart, ${ }^{30}$ appeared also to be comparable to that of the Hong Kong national soccer $\left(21.9(2.1) \mathrm{ml} \cdot \text { beat }^{-1}\right)^{25}$ and rowing $\left(23.8(2.0) \mathrm{ml} \cdot \text { beat }^{-1}\right)^{29}$ teams. For world class endurance athletes, the oxygen pulse can reach as high as $28.5 \mathrm{ml} \cdot$ beat $^{-131}$ and $32.2 \mathrm{ml} \cdot$ beat $^{-132}$ respectively, an indicator of excellent cardiorespiratory efficiency.

The high anaerobic threshold (AT) as a percentage of $\mathrm{VO}_{2 \max }(80.1 \%)$ for the Hong Kong squash team is comparable to that of elite cyclists $(83.0 \%){ }^{33}$ rowers $(83.0 \%),{ }^{34}$ and cross-country skiers $\left.(85.7 \%)\right)^{35}$ This suggests that the players are able to exercise at intensities close to their $\mathrm{VO}_{2 \text { max }}$ without experiencing the deleterious effects of metabolic acidosis. The high AT of the Hong Kong squash players can be attributed, at least in part, to the specific inclusion of a succession of quarter mile runs followed by sprints in their training programme.

Reports of energy expenditure during squash testify to its more intensive aerobic demands compared with tennis and badminton. ${ }^{536}$ The mean heart rates during squash play for physically fit players, ${ }^{37}$ top South African players, ${ }^{5}$ and elite Australian players ${ }^{1}$ were reported to be 167 beats $\cdot \min ^{-1}\left(86 \% \mathrm{HR}_{\text {max }}\right) ; 161$ beats $\cdot \min ^{-1}\left(88 \% \mathrm{HR}_{\max }\right)$, and 172 beats $\cdot \min ^{-1}(91 \%$ $\mathrm{HR}_{\max }$ ) respectively. It is interesting to note that the AT data collected during the present study (168(9.1) beats $\cdot \mathrm{min}^{-1}$ and $\left.89.8(2.9) \% \mathrm{HR}_{\max }\right)$ are similar to the above reports. Therefore it may be reasonable to suggest that a highly competitive squash match may require Hong Kong squash players to exercise at close to their anaerobic thresholds for long periods of the game.

The maximum lactate value (11.0(1.3) $\mathrm{mmol} \cdot$ litre $\left.^{-1}\right)$ from the treadmill running seems to reflect the maximum efforts of the subjects, as a lactate concentration of $12 \mathrm{mmol} \cdot$ litre $^{-1}$ or more has been considered to be a value indicating exhaustion. ${ }^{38}$

\section{Sports specific fitness}

The field test used in this study was devised to measure squash specific fitness, and as such, involved complicated non-rhythmic movements in which speed, rapid force development, and fast reactions are required. In fact a high correlation was found between the field test data and the ranked playing ability of subjects in a previous study ${ }^{14}$ using the same testing equipment method and protocol. The maximum heart rate data $\left(192.7(6.8)\right.$ beats $\left.\cdot \mathrm{min}^{-1}\right)$ and blood lactate values (10.8 (2.2) $\mathrm{mmol} \cdot$ litre $\left.^{-1}\right)$ showed that the players were under maximum load during the field test. These values are similar to those measured in the laboratory (HR 190.7(7.2) beats $\cdot \mathrm{min}^{-1} ; \mathrm{LA}_{\max } 11.0(1.3) \mathrm{mmol} \cdot$ litre $\left.^{-1}\right)$. A fast recovery in exercise heart rate was found, dropping by a mean value of 79.4 beats $\cdot \mathrm{min}^{-1}$ in $5 \mathrm{~min}$ after termination of exercise. A similar finding was observed by Steininger and Wodick ${ }^{14}$ which they attributed to the similar environment, appropriate training preparation, and exercise intensity.

It is interesting to note that mean(s.d.) values of performance and heart rate at the anaerobic threshold for the field test were $19.0(1.4)$ light pulses $\cdot \mathrm{min}^{-1}$ and $171.0(6.0)$ beats $\cdot \mathrm{min}^{-1}$ respectively. The mean(s.d.) heart rate values $\left(159.7(8.1)\right.$ beats $\cdot \mathrm{min}^{-1} ; 175.5(6.6)$ beats $\cdot \mathrm{min}^{-1}$ ) and mean blood lactate values (2.7(1.3) $\mathrm{mmol} \cdot$ litre $^{-1} ; 4.3(1.6) \mathrm{mmol} \cdot$ litre $\left.^{-1}\right)$ were recorded in levels four and five (18 and 20 light pulses $\cdot \mathrm{min}^{-1}$ ) respectively. In previous studies mean heart rate ranged from 161 to 172 beats $\cdot \min ^{-11537}$ and low levels of blood lactate (average between 2 and $4 \mathrm{mmol} \cdot$ litre $\left.^{-1}\right)^{9}{ }^{39-42}$ were found during squash games lasting 30 to $90 \mathrm{~min}$. It seems reasonable to speculate that the intensity of levels four and five stimulates the requirement of actual game energy expenditure for the Hong Kong squash players exercising at close to their anaerobic thresholds. Seven of 10 players in the present study by comparison with three of seven German players ${ }^{14}$ reached level 7 of the field test. The highest attained for the Hong Kong team, was for subject 5, who was selected among the final four and reached level 8 with a finishing time of $1.42 \mathrm{~min}$. The best result for a German team member was to reach level 7 with a finishing time of $1.75 \mathrm{~min}$.

\section{Anaerobic power}

Squash has been described as an aerobic activity with frequent excursions into anaerobic territory. ${ }^{43}$ For professional squash players, Montpetit ${ }^{6}$ had observed a mean rally time of $13.6 \mathrm{~s}$ with $49 \%$ of the rallies lasting $10 \mathrm{~s}$ or less and $80 \%$ lasting less than $20 \mathrm{~s}$. The alactic power index and alactic work index demonstrate an athlete's ability to develop explosive power over $10 \mathrm{~s}$, a requirement for sports involving short maximum efforts such as volleyball, badminton, squash, and starts for running and swimming. The mean(s.d.) alactic power index $\left(15.5(1.8) \mathrm{W} \cdot \mathrm{kg}^{-1}\right)$ and alactic work index $\left(127(17) \mathrm{J} \cdot \mathrm{kg}^{-1}\right)$ measured in this study tended to be higher than those of soccer players, swimmers, long distance runners and touch-rugby players, but appeared to be lower than those of badminton players, volleyball players, and cyclists.

The lactic work index represents the total work done in $\mathrm{J} \cdot \mathrm{kg}^{-1}$ during an all-out sprint for $30 \mathrm{~s}$ and also reveals how well the athlete can sustain a maximum 
power output over that period..$^{44}$ The mean(s.d.) lactic work index $\left(324(29) \mathrm{J} \cdot \mathrm{kg}^{-1}\right)$ of the present study appears to be higher than all those values reported in Table 4 except for badminton players. This may suggest that the Hong Kong squash players possess a high anaerobic power capacity relative to their body weight, one of the important factors in determining success in squash at high level international competition.

\section{Flexibility and muscle strength}

The mean(s.d.) sit-and-reach value measured in the present study $(38.5(6.2) \mathrm{cm}$ ) was average compared to that of the untrained individuals (range $35-40 \mathrm{~cm}$ ). ${ }^{45}$ It is well known that high levels of flexibility are necessary for top performance in many sports and it is an advantage to have above average flexibility levels of the trunk and shoulder regions for racquet sport. ${ }^{46}$ Flexibility training of the hip joint, trunk, and hamstring muscles is important to increase the range of motion by preventing pulls and tears of the thigh which may occur when a squash player is forced into a near 'splits' position. ${ }^{22}$ The tight hamstrings also restrict the pelvis from rotating because of their attachment to the posterior portion of the knee and the tuberosity of the ischium. ${ }^{47}$

Grip strength is important for squash players and the subjects showing a reasonable degree of arm strength $(48.9(5.7) \mathrm{kg})$. It is suggested that with grip strength below $45 \mathrm{~kg}$, forearm muscle fatigue may well loosen the grip to induce inaccuracies towards the end of long matches. ${ }^{2}$ The mean peak torque output of the knee flexion and extension and the comparative data from Hong Kong ${ }^{25}$ and other national sportsmen ${ }^{48-50}$ (all measured in $\mathrm{Nm} \cdot \mathrm{kg}^{-1}$ at $60^{\circ} \cdot \mathrm{s}^{-1}$ ) are presented in Table 5. The knee extension (quadriceps) values (3.11(0.38) $\mathrm{Nm} \cdot \mathrm{kg}^{-1}$ ) in this study were comparatively higher than those of Singapore national squash players, and of the Australian tennis and Hong Kong national soccer teams, but lower than those of Hong Kong elite athletes in badminton and cycling.

It has been known for some time that muscle strength imbalance can predispose an athlete to injury, ${ }^{51}$ and restoring the relationship between hamstring and quadriceps muscle strength pattern is an important preventive measure that should be a primary concern in the training and rehabilitation programme. ${ }^{52}$ Isokinetic testing can serve as a tool for screening. The relation of hamstring to quadriceps strength $(\mathrm{H}: \mathrm{Q}$ ratio), an index of muscle strength balance, varies between $50 \%$ and $62 \%$ in healthy people ${ }^{53}-60 \%$ has been suggested to be ideal..$^{54}{ }^{55}$ The $\mathrm{H}: \mathrm{Q}$ ratio of the Hong Kong squash players $(62.0 \%)$ was similar to that reported for the Singapore national squash players $(59.4 \%)^{48}$ and the Australian junior U20 squash team $(62.0 \%){ }^{49}$ and fell within the recommended range.

This is the first physiological study of Hong Kong elite squash players, and to the authors' knowledge, the most comprehensive published investigation of elite Asian squash athletes. The test data provide a good baseline and reference for coaches, sports physiologists, physiotherapists, and future investigators. Physiological data show that the players tend to be lean in body mass, average in flexibility, and high in aerobic power, anaerobic power, sports specific fitness, and isokinetic knee muscle strength in comparison with data collected from other squash teams and Hong Kong elite sportsmen. Test results suggest that one of the important factors contributing to the success of the Hong Kong squash players recently at the Asian Championship may be their relatively high level of physical fitness demonstrated both in the laboratory and the squash court.

\section{Acknowledgements}

This study was supported in part by a research grant from the Hong Kong Sports Development Board. The authors are grateful to the Hong Kong squash players who participated in the study. They also express their appreciation to Miss Trisha Leahy for her valuable suggestions regarding this manuscript; Miss Yvonne Yuan for her technical assistance; and Miss Queenie Tam for her excellent clerical support.

\section{References}

1 Gillam I, Siviour C, Ellis L, Brown P. The on-court energy demands of squash on élite level players (abstract). In: Draper J, ed. Third report on the national sport research program. Canberra, Australia: Australian Sports Commission, 1990: 35.

2 Sharp C. A testing time. Squash Player Int 1988; 16: $26-7$.

3 Hawkey D. Fit for squash. London: BT Batsford, 1984.

4 Kettunen, T. Squash getting ready for the year 2000. Int Squash Magazine 1991-92; winter: 4.

5 Rensburg JP, Linde VD, Ackerman PC, Kieblock AJ, Strydom NB. Physiological profile of squash players. S Afr Med J 1982; 62: 721-3.

6 Montpetit RR. Applied physiology of squash. Sports Med 1990; 10: $31-4$.

7 Read MTF, Bellamy MJ. Comparison of hamstring/quadriceps isokinetic strength ratios and power in tennis, squash and track athletes. Br J Sports Med 1990; $24: 178-82$.

8 Brooks FBC, Winter EM. A comparison of 3 measures of short duration, maximal performance in trained squash players. $J \mathrm{Hum}$ Movement Stud 1985; 11 : 105-12.

9 Mercier M, Beillot J, Gratas A, Rothcongar P, et al. Adaptation to work load in squash players: laboratory tests and on court recordings. J Sports Med Phys Fitness 1987; 27: 98-104.

10 Singh R, Singh H, Sirisinghe RG. Physiological alterations and leg strength consequent to a 3-month training programme in squash players. Thai J Sports Sci 1991; 1: 30-7.

11 Asian Squash Federation Handbook, 1990; 23.

12 ISPA Proscene. The Chinese are coming. Squash Magazine Int 1991; summer: 6.

13 Jackson AS, Pollock ML. Generalized equations for predicting body density of men. $\mathrm{Br} J$ Nutr 1978; 40: 497-504.

14 Steininger K, Wodick RE. Sports specific fitness testing in squash Br J Sports Med 1987; 21 : 23-6.

15 Telford RD, Minikin BR, Hahn AG, Hooper LA. A simple method for the assessment of general fitness : the tri-level profile. Aust J Sci Med In Sport 1989; 21 : 6-9.

16 Telford RD, Minikin BR, Hooper LA, Hahn AG, Tumility DMcA. The tri-level fitness profile. Excel 1987; 4 : 11-3.

17 Minikin BR, Telford RD. The tri-level profile of well-performed middle and long-distance runners. Excel 1991; 7: 7-8.

18 Wells KF, Dellion EK. The sit and reach of back and leg flexibility. Res $Q$ Exerc Sport 1952; 23 : 115-8.

19 Reilly T. Racquet sports. In: Reilly T, Secher N, Snell P, Williams C, eds. Physiology of sports. London: E. and F. N. Spon, 1990: $337-69$.

20 Lohman TG. Body composition in methodology in sports medicine. Physician Sports Med 1982; 10: 47-57.

21 Pyke S, Elliott C, Pyke E. Performance testing of tennis and squash players. Br J Sports Med 1974; 8: 80-6.

22 Sharp C. Well, just how do you measure up to the tests of competitive fitness? Squash Player Int 1982; 10(7): 26-8.

23 Brownell KD, Steen SN, Wilmore JH. Weight regulation practices in athletes: analysis of metabolic and health effects. Med Sci Sports Exerc 1987; 19: 546-56. 
24 Lam KK, Pang SC, Alan WG, et al. A survey of ventilatory capacity in Chinese subjects in Hong Kong. Ann Human Biol 1982. 9: 459-72.

25 Chin MK, Lo YS, Li CT, So CH. Physiological profiles of Hong Kong élite soccer players. Br J Sports Med 1992; 26: 262-6.

26 Vrijens J, Pannier JL, Bouckaert J. Physiological profile of competitive road cyclists. J Sports Med 1982; 22: 207-16.

27 Lo YS, Chin MK. Echocardiographic left ventricular hypertrophy in Chinese endurance athletes. Br J Sports Med 1990; 24: 274-6.

28 Montpetit RR, Beauchamp L, Leger L. Energy requirements of squash and racquetball. Physician Sports Med 1987; 15: 106-12.

29 Chin MK, So CH, Perry CJ, Wong SK. Maximal aerobic power of Hong Kong élite lightweight rowers. J Strength Conditioning Res (in press).

30 Ästrand PO, Rodahl K. Textbook of work physiology, 3rd ed. New York: McGraw-Hill, 1986

31 Hagerman FC, Hagerman GR, Mickelson TC. Physiological profiles of élite rowers. Physician Sports Med 1979; 7: 74-81.

32 Hagerman FC, Connors MC, Gault JA, Hagerman GR, Polinaki WJ. Energy expenditure during simulated rowing. Appl Physiol $1978 ; 45: 87-93$.

33 Faria IF, Faria EW, Roberts S, Yoshimura D. Comparison of physical and physiological characteristics in élite young and mature cyclists. Res Q Exerc Sport 1989; 60 : 388-95.

34 Mickelson TC, Hagerman FC. Anaerobic threshold measurements of elite oarsmen. Med Sci Sports Exerc 1982; 14: 440-4.

35 Rusko H, Rahkila P, Karuinen E. Anaerobic threshold, skeletal muscle enzymes and fiber composition in young female crosscountry skiers. Acta Physiol Scand 1980; 108: 263-8.

36 Brooks GA, Fahey TD. Exercise physiology: human bioenergetics and its application. New York: John Wiley.

37 Montgomery DL, Maclcolm V, McDonnell E. A comparison of the intensity of play in squash and running. Physician Sports Med 1981; 9: 116-9.

38 Mader $\mathrm{A}$, Liesen $\mathrm{H}$, Heck $\mathrm{H}$, Philipe $\mathrm{H}$, Schuerch PM, Hollmann W. Zur Beurteilung der sportartspezifischen Ausdauerleistungsfehigkeit im Labor. Sportarzt u. Sportmed 1976; 27(4): 80; and 27(5): 109.

39 Beauchamp L, Montpetit RR. The oxygen consumption during racquet ball and squash matches. Can J Appl Sports Sci 1980; 5: $273 \mathrm{~A}$.
40 Beaudin P, Zapiec C, Mongometry D. Heart rate response and lactic acid concentration in squash players. Res $Q$ Exerc Sport 1978; 49: 406-12.

41 Garden G, Hale PJ, Horrocks PM, Crase J, Hammon V. Metabolic and hormonal responses during squash. Eur J Appl Physiol 1986; 55: $445-9$.

42 Noakes TD, Cowling JR, Gevers W, Van Niekerk JP. The metabolic response to squash including the influence of preexercise carbohydrate ingestion. $S$ Afr Med J 1982; 62: 721-3.

43 Sharp C. Fitness for squash; how to build your aerobic power. Squash Player Int 1979; 8(3): 15-7.

44 Minikin B. Hints for coaches on interpreting the tri-level profile of general fitness. Sports Coach 1990; 13: 19-23.

45 Estrand J. Soccer injuries and their prevention (thesis). Linkoping University Medical Dissertation 130. 1982.

46 Ackland TR, Bloomfield TR. Functional anatomy. In: Bloomfield I Fricker PA, Fitch KD, eds. Textbook of science and medicine in sports. Victoria: Blackwell Scientific Publications, 1992: 2-28.

47 Cailliet R. Low back pain syndrome. Philadelphia: Davis FA, 1981.

48 Chook KK, Teh KC, Giam CK. The isokinetic strength of dominant quadriceps and hamstring muscles of 47 Singapore national sportsmen. In: Giam CK, Teh KC, eds. Proceedings of 2nd International Sports Science Conference-Toward Sports Excellence (11-13 September 1986), Singapore: Singapore Sports Council 1986: 127-33.

49 Telford RD, Tumility DCA, Hahn A. Leg strength of athletes in 14 different sports. Sports Sci Med Q 1985; 2 : 6-9.

50 Li G, Chen $X$, Zhang $W$. Isokinetic strength and endurance of quadriceps and hamstring muscles in élite Chinese athletes. Chin J Sports Med 1968; 7: 143-8.

51 Oberg B, Moller M, Gilliquist J, Estrand J. Isokinetic torque levels for knee extensors and knee flexors in soccer players. Int J Sports Med 1986; 7: 50-3.

52 Poulmedis P. Isokinetic maximal torque power of Greek élite soccer players. J Orthop Sports Phys Ther $1985 ; 6$ : 293-5.

53 Knapik J, Ramos M. Isokinetic and isometric torque relationship in the human body. Arch Phys Med Rehabil 1980; 61: 64-7.

54 Bender JA, Pierson JK, Kaplan HD, Johnson AJ. Factors affecting the occurrence of knee injuries. JAPMR 1964; 18: 130-4.

55 Burkett LS. Causative factors in hamstring strains. Med Sci Sports Exerc 1970; 2: 39-42. 